\title{
Pemanfaatan Berbagai Jenis Pupuk Organik Hayati terhadap Produksi Bawang Merah (Allium ascalonicum L.) di Tanah Pasang Surut Tipe Luapan C Asal Banyuurip
}

\author{
Utilization of Various Types of Biofertilizer on the Production of Shallots (Allium \\ ascalonicum L.) in Overflow Type C Tidal Soils from Banyuurip \\ Neni Marlina ${ }^{1 *}$, Nurbaiti Amir $^{2}$, dan Berliana Palmasari ${ }^{2}$ \\ ${ }^{1}$ Fakultas Pertanian Universitas Palembang, Palembang, Sumatera Selatan 30139 \\ ${ }^{2}$ Fakultas Pertanian Universitas Muhammadiyah Palembang, \\ Palembang, Sumatera Selatan 30116 \\ ${ }^{*}$ Penulis untuk korespondensi: marlina002@yahoo.com
}

\begin{abstract}
Tidal land has considerable potential to be used as agricultural land, one of which is for shallot, but the obstacles faced in this tidal land are high soil acidity and low soil fertility. Therefore, to increase the production of onion plants can be given biological organic fertilizer. This study aimed to analyze the right type of biological organic fertilizer in increasing the production of shallots. This research has been carried out at the Greenhouse in Palembang. The design used is Factorial Randomized Completely Block Design with consisted of 4 treatment factors with 6 replications for each treatment. The first factor was control $\left(\mathrm{O}_{0}\right)$, the second factor was biofertilizer enriched with Azospirillum $\left(\mathrm{O}_{1}\right)$ bacteria, the third factor was biofertilizer enriched with phosphate solvent bacteria (BPF) $\left(\mathrm{O}_{2}\right)$, and the fourth factor was biofertilizers enriched with Azospirillum and BPF bacteria. The results showed that the treatment of Azospirillum and BPF-enriched biofertilizers gave the best production per hill of onion by $85.33 \mathrm{~g}$.
\end{abstract}

Keywords: azospirillum, phosphate solvent bacteria, shallot, tidal land, type of biofertlizer

\begin{abstract}
ABSTRAK
Lahan pasang surut memiliki potensi yang cukup besar untuk dapat digunakan sebagai lahan pertanian, salah satunya untuk tanaman bawang merah, namun kendala yang dihadapi di lahan pasang surut ini adalah tingginya kemasaman tanah dan rendahnya kesuburan tanah. Oleh karena itu untuk meningkatkan produksi tanaman bawang merah dapat diberikan pupuk organik hayati. Penelitian ini bertujuan mendapatkan jenis pupuk organik hayati yang tepat dalam meningkatkan produksi tanaman bawang merah. Penelitian ini telah dilaksanakan di Rumah Kaca di Palembang. Rancangan yang digunakan adalah RAK dengan 4 perlakuan yang diulang 6 kali. Perlakuannya sebagai berikut: kontrol $\left(\mathrm{O}_{0}\right)$, pupuk organik hayati yang diperkaya bakteri Azospirillum $\left(\mathrm{O}_{1}\right)$, pupuk organik hayati yang diperkaya bakteri pelarut fosfat $(\mathrm{BPF})\left(\mathrm{O}_{2}\right)$, dan pupuk organik hayati yang diperkaya bakteri Azospirillum dan BPF. Hasil penelitian menunjukkan bahwa perlakuan pupuk organik hayati yang diperkaya Azospirillum dan BPF memberikan produksi per rumpun terbaik terhadap bawang merah sebesar $85,33 \mathrm{~g}$.
\end{abstract}

Kata kunci: pupuk organik hayati, Azospirillum, bakteri pelarut fosfat, bawang merah, tanah pasang surut 


\section{PENDAHULUAN}

Prospek pengembangan bawang
merah cukup baik karena banyak dibutuhkan orang sebagai bumbu masakan dan obat tradisional. Peningkatan kebutuhan akan bawang merah seiring dengan pertambahan jumlah penduduk dan daya belinya. Agar kebutuhan dapat selalu dipenuhi maka harus diimbangi dengan jumlah produksinya (Putra 2010).

Salah satu lahan yang sangat potensial dimanfaatkan untuk peningkatan kebutuhan bawang merah di Sumatera Selatan adalah lahan pasang surut. Namun lahan pasang surut ini belum dapat dimanfaatkan secara optimal untuk peningkatan produksi bawang merah. Menurut Maas (2003), salah satu kendala yang ditemui di lahan ini masalah kesuburan tanah.

Selanjutnya ditambahkan Alwi (2014), lahan pasang surut mempunyai kesuburan tanah rendah, kemasaman tanah tinggi karena kelarutan $\mathrm{Al}, \mathrm{Fe}$ dan $\mathrm{SO}_{4}{ }^{2-}$ yang tinggi, ketersediaan hara menurun. Potensi untuk mengembangkan bawang merah di lahan pasang surut sangat tinggi tetapi diperlukan diberikan pupuk baik pupuk anorganik maupun pupuk organik (salah satunya pupuk organik yang diperkaya bakteri).

Pupuk organik yang diperkaya bakteri disebut pupuk organik hayati. Pupuk organik hayati dapat berperan dalam membantu menyediakan unsur hara karena aktivitas bakteri yang ada di pupuk organik hayati tersebut.

Pupuk organik hayati ini telah diuji coba pada tanaman padi (Marlina et al. 2014; 2016; 2017), jagung manis (Marlina et al. 2017) dan semuanya dapat meningkatkan produksi pada tanaman padi dan jagung manis, oleh karena itu peneliti ingin mencoba pada tanaman bawang merah. Tujuan penelitian ini adalah mendapatkan jenis pupuk organik hayati yang tepat dalam meningkatkan produksi tanaman bawang merah.

\section{BAHAN DAN METODE}

Penelitian ini telah dilaksanakan di Rumah Kaca di Palembang. Rancangan yang digunakan adalah RAK dengan 4 perlakuan yang diulang 6 kali. Perlakuannya sebagai berikut: kontrol $\left(\mathrm{O}_{0}\right)$, pupuk organik hayati yang diperkaya bakteri Azospirillum $\left(\mathrm{O}_{1}\right)$, pupuk organik hayati yang diperkaya bakteri pelarut fosfat (BPF) $\left(\mathrm{O}_{2}\right)$, dan pupuk organik hayati yang diperkaya bakteri Azospirillum dan BPF. Uji lanjut yang digunakan adalah uji BNJ (Beda Nyata Jujur). Analisis statistik menggunakan program SAS 9.1.3 Portable.

\section{Pembuatan Pupuk Organik Hayati}

Pupuk kandang kotoran ayam: dedak: bakteri Azospirillum (10 kg: $1 \mathrm{~kg}: 10$ $\mathrm{mL}$ ), dengan cara pupuk kandang kotoran ayam dengan dedak diaduk menjadi satu dan diinkubasi selama 1 bulan, setelah itu disterilisasi dengan digonseng, setelah dingin diberi bakteri Azospirillum.

\section{Persiapan Tanah}

Tanah diambil dari lahan pasang surut (Desa Banyuurip Kecamatan Tanjung Lago Kabupaten Banyuasin), kemudian tanah tersebut dijemur sampai kering, setelah itu ditimbang sebanyak $10 \mathrm{~kg}$, lalu dimasukkan kedalam polybag.

\section{Penyiapan Bibit Bawang}

Bibit bawang merah yang digunakan yaitu Bima Brebes sebanyak 2 umbi. Umbi yang digunakan berasal dari tanaman umur 70-80 setelah tanam, dengan ukuran diameter 1,5-1,8 $\mathrm{cm}$ atau bobot 3-5g. Umbi segar dan sehat, tidak keriput, berwarna cerah (tidak kusam), dan tunasnya sudah sampai ke ujung umbi. Sebelum penanaman ujung umbi dilakukan pemotongan 1/3 bagian atasnya dan perendaman menggunakan ZPT atonik selama 15 menit.

\section{Pemupukan}

Pupuk organik hayati diberikan sesuai dengan perlakuan dan diberikan satu hari sebelum tanam, sedangkan pupuk 
anorganik diberikan $1 / 2$ dari dosis anjuran dan dilakukan saat tanam.

\section{Pemeliharaan}

Pemeliharaan meliputi penyiraman dilakukan 2 dua kali sehari yaitu pagi dan sore hari dan pengendalian gulma secara manual menggunakan tangan.

\section{Panen}

Panen dilakukan pada saat bawang merah berumur 12 minggu setelah tanam (MST) setelah $75 \%$ daun bagian atas menguning dan rebah.

\section{Peubah yang Diamati}

Peubah yang diamati meliputi tinggi tanaman, jumlah daun, jumlah anakan, diameter umbi, bobot basah umbi per sampel dan produksi per rumpun.

\section{HASIL}

Berdasarkan hasil analisis keragaman (Tabel 1) menunjukkan bahwa perlakuan jenis pupuk organik hayati berpengaruh sangat nyata terhadap semua peubah yang diamati.

Tabel 1. Hasil analisis keragaman pengaruh jenis pupuk organik hayati terhadap peubah yang diamati

\begin{tabular}{lcc}
\hline Peubah yang Diamati & Jenis Pupuk Organik Hayati & Koefisien Keragaman $(\%)$ \\
\hline Tinggi tanaman (cm) & $* *$ & 3,79 \\
Jumlah daun (helai) & $* *$ & 9,08 \\
Jumlah anakan (anakan) & $* *$ & 12,78 \\
Diameter umbi (cm) & $* *$ & 9,79 \\
Berat umbi per sample $(\mathrm{g})$ & $* *$ & 6,97 \\
Produksi per rumpun $(\mathrm{g})$ & $* *$ & 9,41 \\
\hline
\end{tabular}

Keterangan: $* *=$ berpengaruh sangat nyata

Hasil uji Beda Nyata Jujur (BNJ) pengaruh perlakuan jenis pupuk organik hayati terhadap peubah yang diamati dapat dilihat pada Tabel 2 dan 3. Tabel 2 dan 3 menunjukkan bahwa perlakuan pupuk organik hayati yang diperkaya Azospirillum dan BPF berbeda sangat nyata terhadap perlakuan tanpa jenis pupuk organik hayati, namun berbeda tidak nyata dengan pupuk organik hayati yang diperkaya Azospirillum dengan BPF.

\section{PEMBAHASAN}

Hasil analisis tanah sebelum tanam di PT Bina Sawit Makmur (2016) dan kriteria penelitian menurut PPT (1983) dan Balai Penelitian Tanah (2005) menunjukkan tanah yang digunakan pada penelitian ini tergolong masam $\left(\mathrm{pH} \mathrm{H}_{2} \mathrm{O}=5,35\right)$ dengan kapasitas tukar kation tergolong sedang $(24,43 \mathrm{me} / 100 \mathrm{~g})$, kandungan C-organik $6,20 \%$ tergolong sangat tinggi, kandungan $\mathrm{N}$-total tergolong sedang $0,42 \%, \mathrm{P}$ tersedia tergolong sangat tinggi $(76,75 \mathrm{ppm})$, basa tertukar seperti Ca-dd 0,14 me/100g tergolong sangat rendah, $\mathrm{Mg}$-dd 0,14 me/100 tergolong sangat rendah, K-dd 0,30 me/100g tergolong rendah, Na-dd 1,47 me/100g tergolong sangat tinggi, dengan Kejenuhan Basa 8,39\% tergolong sangat rendah, dengan tekstur tanah mengandung $70,00 \%$ pasir, $13,00 \%$ debu dan $17,00 \%$ liat dan tergolong tekstur tanah lempung berpasir.

Tanah yang memiliki tekstur lempung berpasir ini mengandung pasir lebih banyak yaitu 70,00\% sehingga tanah tersebut bersifat porous dan memiliki kemampuan yang rendah dalam memegang unsur hara dan air, akibat dari mudahnya pencucian unsur hara yang terjadi, oleh karena itu tanah pasang surut ini perlu diberi pupuk organik untuk meningkatkan kemampuan tanah memegang unsur hara dan air.

Hasil uji BNJ terlihat bahwa perlakuan jenis pupuk organik hayati yang diperkaya Azospirillum dan bakteri pelarut fosfat memberikan pertumbuhan dan 
produksi terbaik bila dibandingkan dengan perlakuan tanpa pupuk organik hayati dan pupuk organik hayati yang lainnya. Hal ini disebabkan karena jenis pupuk organik hayati yang diperkaya Azospirillum dan bakteri pelarut fosfat merupakan jenis pupuk yang mampu dan cukup dalam mendukung pertumbuhan dan produksi tanaman bawang merah.

Tabel 2. Pengaruh jenis pupuk organik hayati terhadap tinggi tanaman, jumlah daun dan jumlah anakan

\begin{tabular}{lccc}
\hline Jenis Pupuk Organik Hayati & Tinggi Tanaman $(\mathrm{cm})$ & $\begin{array}{l}\text { Jumlah Daun } \\
\text { (Helai) }\end{array}$ & $\begin{array}{l}\text { Jumlah Anakan } \\
\text { (Anakan) }\end{array}$ \\
\hline $\begin{array}{l}\text { Tanpa } \\
\begin{array}{l}\text { Pupuk organik hayati yang } \\
\text { diperkaya Azospirillum }\end{array}\end{array}$ & $36,52^{\mathrm{a}}$ & $14,00^{\mathrm{a}}$ & $5,00^{\mathrm{a}}$ \\
$\begin{array}{l}\text { Pupuk organik hayati yang } \\
\text { diperkaya BPF }\end{array}$ & $38,67^{\mathrm{a}}$ & $16,83^{\mathrm{ab}}$ & $6,17^{\mathrm{ab}}$ \\
$\begin{array}{l}\text { Pupuk organik hayati yang } \\
\text { diperkaya Azospirillum dan BPF }\end{array}$ & $39,40^{\mathrm{b}}$ & $17,50^{\mathrm{bc}}$ & $6,67^{\mathrm{ab}}$ \\
\hline BNJ 0,01 & $43,33^{\mathrm{b}}$ & $20,50^{\mathrm{c}}$ & $7,50^{\mathrm{b}}$ \\
\hline Keterangan: Angkang & 3,21 & 3,35 & 1,74 \\
\hline
\end{tabular}

Keterangan: Angka-angka yang diikuti oleh huruf yang sama pada kolom yang sama berarti berbeda tidak nyata

Tabel 3. Pengaruh jenis pupuk organik terhadap berat umbi per sample dan produksi per rumpun

\begin{tabular}{lcccc}
\hline Jenis Pupuk Organik Hayati & $\begin{array}{l}\text { Diameter } \\
\text { Umbi }(\mathrm{cm})\end{array}$ & $\begin{array}{l}\text { Berat Umbi Per } \\
\text { Sample }(\mathrm{g})\end{array}$ & $\begin{array}{l}\text { Produksi Per } \\
\text { Rumpun }(\mathrm{g})\end{array}$ & $\begin{array}{c}\text { Peningkatan } \\
\text { Produksi (\%) }\end{array}$ \\
\hline $\begin{array}{l}\text { Tanpa } \\
\begin{array}{l}\text { Pupuk organik hayati yang } \\
\text { diperkaya Azospirillum }\end{array}\end{array}$ & $1,15^{\mathrm{a}}$ & $10,00^{\mathrm{a}}$ & $61,50^{\mathrm{a}}$ & - \\
$\begin{array}{l}\text { Pupuk organik hayati yang } \\
\text { diperkaya BPF }\end{array}$ & $1,45^{\mathrm{a}}$ & $11,67^{\mathrm{ab}}$ & $71,33^{\mathrm{ab}}$ & 15,98 \\
$\begin{array}{l}\text { Pupuk organik hayati yang } \\
\text { diperkaya Azospirillum dan BPF }\end{array}$ & $1,78^{\mathrm{b}}$ & $12,50^{\mathrm{b}}$ & $74,83^{\mathrm{ab}}$ & 21,67 \\
\hline BNJ 0,01 & 0,31 & 1,76 & $85,33^{\mathrm{b}}$ & 38,75 \\
\hline Ket & & 14,78 & \\
\hline
\end{tabular}

Keterangan: Angka-angka yang diikuti oleh huruf yang sama pada kolom yang sama berarti berbeda tidak nyata.

Unsur hara $\mathrm{N}$, $\mathrm{P}$, dan $\mathrm{K}$ yang terkandung dalam jenis pupuk organik hayati (pupuk kotoran ayam yang diperkaya Azospirillum dan bakteri pelarut fosfat) telah mencukupi kebutuhan hara bagi tanaman bawang merah. Hal ini tidak terlepas dari peranan bakteri Azospirillum dan bakteri pelarut fosfat yang membantu menyediakan unsur hara $\mathrm{N}, \mathrm{P}$ dan $\mathrm{K}$. Unsur hara $\mathrm{N}$ tersedia dengan adanya bantuan bakteri Azospirillum yang memiliki enzim nitrogenase yang dapat mengubah $\mathrm{N}_{2}$ dari hasil fiksasi menjadi amonium $\left(\mathrm{NH}_{4}{ }^{+}\right)$dan unsur hara $\mathrm{P}$ dan $\mathrm{K}$ yang tersedia dengan adanya bakteri pelarut fosfat yang memiliki enzim fosfatase yang dapat melarutkan unsur hara $\mathrm{P}$.

Selain itu bakteri pelarut fosfat dapat meningkatkan aktivitas enzim fosfomonoesterase asam dan basa yang selanjutnya berperan dalam penyediaan hara (P tersedia) di dalam tanah (Widiwati et al. 2010, Sulisasih et al. 2010). Keberadaan $\mathrm{P}$ tersedia dalam tanah meningkatkan hasil umbi bawang merah (Firmansyah et al. 2015).

Unsur hara $\mathrm{N}$ dapat meningkatkan pembentukan vegetatif seperti jumlah anakan dan jumlah daun. Menurut Mukhlis (2011), banyaknya jumlah daun yang terbentuk berarti luas daun menjadi lebih 
lebar, maka kemampuan daun dalam menerima cahaya untuk proses fotosintes menjadi lebih besar dalam menghasilkan karbohidrat dan akan ditranslokasikan kebagian umbi sehingga mempengaruhi besar dan berat umbi.

Kandungan $\mathrm{K}$ yang tinggi menyebabkan ion $\mathrm{K}^{+}$yang mengikat air dalam tubuh tanaman akan mempercepat proses fotosintesis. Hasil fotosintesis inilah yang merangsang pembentukan umbi menjadi lebih besar sehingga dapat meningkatkan bobot kering tanaman. Berdasarkan hasil penelitian Napitupulu dan Winarto (2009) pemberian pupuk K dalam tanah yang cukup memberikan pertumbuhan bawang merah lebih optimal dan menunjukan hasil yang baik. Penambahan pupuk $\mathrm{K}$ berpengaruh sangat nyata terhadap bobot kering tanaman per rumpun dan $\mathrm{K}$ berperan dalam proses fotosintesis serta dapat meningkatkan bobot umbi.

Peningkatan produksi per rumpun meningkat sebanyak $38,75 \%$ pada pemberian pupuk organik hayati yang diperkaya bakteri Azospirillum dan bakteri pelarut fosfat bila dibandingkan dengan tanpa pemberian pupuk organik hayati. Hal ini menunjukkan bahwa pupuk organik hayati yang diperkaya bakteri Azospirillum dan bakteri pelarut fosfat telah membuktikan keefektifannya dalam menyumbangkan unsur hara $\mathrm{N}, \mathrm{P}$, dan $\mathrm{K}$ dengan baik, sehingga meningkatkan produksi bawang merah. Hasil produksi per rumpun yang dicapai sebanyak $85,33 \mathrm{~g}$ mendekati deskripsi nasional $(72,00 \mathrm{~g})$. Untuk mempertahankan agar bawang merah ini produksinya meningkat maka pemberian pupuk organik hayati ini harus tetap diberikan pada tanaman bawang merah yang ditanam di tanah maupun lahan pasang surut.

Rendahnya produksi bawang merah pada perlakuan tanpa pupuk organik hayati, dan dapat dibuktikan dari setiap peubah yang diamati. Hal ini disebabkan karena tanah ini memanfaatkan unsur hara yang ada di dalam tanah saja, sehingga tanaman mengalami kekurangan unsur hara $\mathrm{N}, \mathrm{P}$ dan K. Hal ini sejalan dengan hasil penelitian Afrilliana et al. (2017), tanaman bawang merah yang tanpa diberi pupuk akan memberikan hasil yang rendah.

\section{KESIMPULAN}

Perlakuan jenis pupuk organik hayati yang diperkaya bakteri Azospirillum dan bakteri pelarut fosfat dapat memberikan pertumbuhan dan produksi per rumpun bawang merah sebanyak 85,33 g dengan peningkatan produksi sebsar $38,75 \%$.

\section{DAFTAR PUSTAKA}

Afrilliana N, Darmawati A, dan Sumarsono. 2017. Pertumbuhan dan hasil panen bawang merah (Allium ascalonicum L.) akibat penambahan pupuk $\mathrm{kcl}$ berbasis pupuk organik berbeda. $J$. Agro Complex. 1(3):126-134.

Alwi M. 2014. Prospek lahan rawa pasang surut untuk tanaman padi. Prosiding Seminar "Inovasi Teknology Pertanian Spesifik Lokasi". Banjarbaru 6-7 Agustus 2014.

Firmansyah I, Liferdi, Khaiririyatun N, dan M.P. Yufdy. 2015. Pertumbuhan dan Hasil Bawang Merah yang diaplikasi Pupuk Organik dan Pupuk Hayati pada Tanah Alluvial. $J$. Hort. 25(2):133-141

Marlina N, Gofar N, Subakti AHPK, dan Rahim AM. 2014. Improvement of rice growth and productovity through balance application of inorganic fertilizer and biofertilizer in inceptisol soil of lowland swamp area. Journal Agrivita. 36(1):48-56.

Marlina N, Asmawati, Zairani FY, dan Rivai S. 2016, Pengaruh pupuk organik hayati terhadap $\mathrm{C} / \mathrm{N}$ ratio, $\mathrm{N}, \mathrm{P}, \mathrm{K}$, dan pertumbuhan dan produksi tanaman padi di tanah pasang surut. Prosiding Seminar Nasional dan Peragi Bogor tanggal 27 April 2016. Bogor. 
Marlina N, Rompas JP, Marlina, dan Musbik. 2017. Nutrient uptake of npk and result of some rice varieties in tidal land by using combination of organic and inorganic fertilizer. AIP Conference Proceedings. 1885.020310 (2017).

Marlina N, Amir N, Aminah RIS, Nasser GA, Purwanti Y, Nisfuriah L, dan Asmawati. 2017. Organic and inorganic fertilizer application on npk uptake and production of sweet corn in inceptisol soil of lowland swamp area. MATEC Web of Conference 97-01106(2017).

Mulyani O, Trinurani E, Sandrawati A. 2007. Pengaruh Kompos Sampah Kota dan Pupuk Kandang Ayam Terhadap Beberapa Sifat Kimia Tanah dan Hasil Tanaman Jagung Manis Pada Fluventic Eutrudepts Asla Jati Nangor Kabupaten Sumedang. Lembaga Penelitian, Fakultas Pertanian, Universitas Padjajaran, Bandung.

Maas A. 2003. Pengelolaan Lahan Rawa Berkelanjutan dan Berwawasan Lingkungan. Pusat Studi
Sumberdaya Lahan. Universitas Gajah Mada. Yogyakarta. Hal 156. Napitupulu D dan Winarto L. 2009. Pengaruh pemberian pupuk $\mathrm{N}$ dan $\mathrm{K}$ terhadap pertumbuhan dan produksi bawang merah. J Hort. 20(1):22-35

Pusat Penelitian Tanah. 1983. Terms of Reference Type. As. P3TT Bogor.

Putra AAG. 2010. Pengaruh jarak tanam dan dosis pupuk kandang ayam terhadap pertumbuhan dan haisl bawang meran (Allium ascalonicum L.) di lahan kering beriklim basah. Gane C Swara. 4(1):22-24.

Suliasih S, Widawati dan Muhharam A. 2010. Aplikasi pupuk organik untuk meningkatkan pertumbuhan tanaman tomat dan aktivitas mikroba tanah. J. Hort. 20(30):24146.

Widawati, Suliasih S, dan Syaifuddin. 2010. Pengaruh intoduksi kompos plus terhadap produksi bobot kering daun kumis kucing (Ortlosiphon aristatus BI. Miq) pada tiga macam media tanah. J. Biol Indonesia. $3(1): 245-53$ 